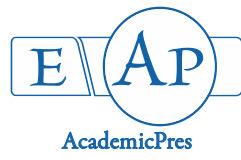

\title{
Fruit and Juice Metric Characteristics of Two Yellow Passion Fruit (Passiflora edulis Degener) Genotypes Grown in Southeastern Nigeria
}

\author{
Okorie O. NDUKWE ${ }^{1 *}$, Paul K. BAIYERI ${ }^{2}$ \\ ${ }^{1}$ Nnamdi Azikiwe University, Faculty of Agriculture, Department of Crop Science and Horticulture, Awka, Anambra State, \\ Nigeria; oo.ndukwe@unizik.edu.ng (*correspondingauthor) \\ ${ }^{2}$ University of Nigeria, Faculty of Agriculture, Department of Crop Science, Nsukka, Enugu, Nigeria; paul.baiyeri@unn.edu.ng
}

\begin{abstract}
An investigation was undertaken to determine the fruit and juice metric traits of fresh fruits obtained from two yellow passion fruit genotypes grown in south-eastern Nigeria in two seasons. The passion fruit genotypes (Conventional and KPF-4) received $0,10,20,30,40 \mathrm{t} \mathrm{ha}^{-1}$ poultry manure (PM) rates in 2014 and $0,10,20 \mathrm{t} \mathrm{ha}^{-1} \mathrm{PM}, 5 \mathrm{t} \mathrm{ha}{ }^{-1} \mathrm{PM}+200 \mathrm{~kg} \mathrm{ha}^{-1} \mathrm{NPK}$ 15:15:15, $10 \mathrm{t} \mathrm{ha}^{-1} \mathrm{PM}+200 \mathrm{~kg} \mathrm{ha}^{-1} \mathrm{NPK}$ and $400 \mathrm{~kg} \mathrm{ha}^{-1} \mathrm{NPK}$ in 2016. Ten ripe and freshly dropped fruits in 2015 and 2017 were picked and taken to the laboratory. Fruit and juice metric traits (such as fruit length, circumference, pulp weight, juice volume and weight) were measured. Data collected were subjected to analysis of variance following the procedure for split-plot experiment in completely randomized design. KPF- 4 significantly $(\mathrm{p}<0.05)$ produced longer, wider and heavier fruits than the Conventional in 2015 whereas in 2017 all the fruit metric traits did not significantly ( $p>0.05)$ differ between the genotypes. Juice volume $(682 \mathrm{ml})$ and pulp fresh weight $(942 \mathrm{~g})$ in 2015 were significantly highest in the Conventional when they received 20 or $40 \mathrm{t} \mathrm{ha}^{-1} \mathrm{PM}$. Application of $10 \mathrm{t} \mathrm{ha}^{-1} \mathrm{PM}+200 \mathrm{~kg} \mathrm{ha}^{-1} \mathrm{NPK}$ in 2016 enhanced the production of highest juice volume $(723 \mathrm{ml})$ and pulp fresh weight $(770 \mathrm{~g})$ in the Conventional. Juice percentage and fruit metric traits of yellow passion fruit could be enhanced with the application $20 \mathrm{tha} \mathrm{a}^{-1} \mathrm{PM}$, considering lesser cost of PM procurement, or combined application of $10 \mathrm{tha}^{-1} \mathrm{PM}+200 \mathrm{~kg} \mathrm{ha}^{-1} \mathrm{NPK}$.
\end{abstract}

Keywords: characteristics; fertilizer; fruit juice; genotype; inorganic; organic; yellow passion fruit

\section{Introduction}

Passion fruit (Passiflora edulis Degener) belongs to the Passifloraceae family. Edible varieties include the yellow and purple passion fruit. The major varieties that are grown worldwide include yellow (Passiflora edulis f. flavicarpa Degener), purple (Passiflora edulis Sims f. edulis) and giant variety called giant granadilla (Passiflora quadrangularis) (Ferreres et al., 2007). The crop, which is a vine, is cultivated majorly because of the edible pulp and juice. The fresh ripe passion fruits can be sold directly but the pulp and juice can also be consumed raw or as frozen pulps, jams, yoghurts (da Silva et al., 2015). The juice is also blended with other fruits in wine and juice industries for the production of other unique products. Presently, passion fruit juice is utilized in some fruit markets and smoothie outlets and stores in Nigeria (Field survey, Personal communication). But, the crop is relatively known by few farmers in southeastern Nigeria.
The undiluted juice of passion fruit is highly concentrated and it has rich flavor and strong, but pleasant aroma (Knight and Sauls, 2005). Passion fruit juice is a good source of ascorbic acid (vitamin C) and carotenoids (vitamin A). The passion fruit seed which is advised to be consumed together with the pulp is a rich source of magnesium, an essential mineral that plays a prominent role in carbohydrate metabolism, proper heartbeat and nerve transmission (Sano et al., 2011). The seeds also contain piceatanol and scirpusin B, polyphenolic compounds that have strong antioxidant activity. It offers cardiovascular health benefits and exerts vasorelaxant effect (Sano et al., 2011). According to Chau and Huang (2004) and Chau et al. (2005), the seeds also possess insoluble dietary fiber $(64$ $\mathrm{g} / 100 \mathrm{~g}$ ) which offer an effective functional ingredient to promote intestinal function.

Realizing the importance of passion fruit, the Kenya Agricultural Research and Livestock Organization (KARLO) developed KPF-4 among other two (KPF 11 and KPF 12) hybrids (KARLOS, 2014) and were released in 2011. Mwirigi et al. (2016) noted that KPF-4 has higher preference than the other two hybrids as it has higher fruit 
yields, juice content and quality. However, the external and internal characteristics of passion fruit have been noted to be influenced by fertilization, among other factors (Pacheco et al., 2017). But the characteristics response of passion fruit to fertilization vary according to the species, amount and types of fertilizers utilized (Weston and Barth, 1997; Mattheis and Fellman, 1999; Aular et al., 2014). The fruit and juice metric characteristics of KPF-4 have not been elucidated. Hence, the objective of the present study was to evaluate the fruit and metric traits of the yellow passion fruit hybrid (KPF-4) alongside an existing yellow passion fruit genotype in Nigeria as influenced by fertilizer application.

\section{Materials and Methods}

\section{Experimental site, laboratory and fruits utilized}

Fresh yellow passion fruits were picked from passion fruit vines established in the teaching and research farm of the Department of Crop Science, University of Nigeria, Nsukka (longitude $07^{\circ} 29^{\prime} \mathrm{N}$, latitude $06^{\circ} 51^{\prime} \mathrm{E}$ with $400 \mathrm{~m}$ above sea level). During the field study, the total annual rainfall was $1410 \mathrm{~mm}$ and $1554 \mathrm{~mm}$, respectively in 2015 and 2017. Mean minimum and maximum temperatures were $21{ }^{\circ} \mathrm{C}$ and $30{ }^{\circ} \mathrm{C}$, respectively and average relative humidity was $71 \%$ and $53 \%$ in 2015 and 2017, respectively.

In 2014 (first year of transplanting), two yellow passion fruit genotypes (Conventional and $\mathrm{KPF}-4$ ) received five poultry manure rates $\left(0,10,20,30,40 \mathrm{t} \mathrm{ha}^{-1}\right)$. In 2016 (second year of transplanting), the two passion fruit genotypes were treated with six fertilizer treatments namely no fertilizer, $10 \mathrm{t} /$ ha poultry manure (PM), $20 \mathrm{t} \mathrm{ha}^{-1} \mathrm{PM}, 5 \mathrm{t}$ ha ${ }^{-1} \mathrm{PM}+200 \mathrm{~kg} \mathrm{ha}^{-1} \mathrm{NPK}, 10 \mathrm{t} \mathrm{ha}^{-1} \mathrm{PM}+200 \mathrm{~kg} \mathrm{ha}^{-1}$ NPK, $400 \mathrm{~kg} \mathrm{ha}^{-1} \mathrm{NPK}$. The grade of the inorganic fertilizer was NPK 15:15:15. The physico-chemical properties of the soil and poultry manure used are presented in Table 1.
The choice of combining organic and inorganic fertilizers in the 2016 was because of superior and sustainable performance of passion fruit as regards growth and fruit yield with $20 \mathrm{t} \mathrm{ha}^{-1}$ poultry manure application over other PM rates (Ndukwe and Baiyeri, 2018a). In both crop cycles, the experimental layout was split-plot replicated three times. In each cropping season, the main plots were assigned to the genotypes while the sub-plots were allocated to the fertilizer treatments. The soil amendments were applied at one month after transplanting. Other cultural practices were as described by Ndukwe and Baiyeri (2018a).

Naturally, the yellow passion fruit turns from green to yellow on the vines, thereafter the fruit abscise and drop on the ground when matured. Hence, ten ripe and fresh passion fruits per replicate were picked from the ground directly under the vines according to the treatment and treatment combinations. The juice extractions were done in the laboratory of Food Science and Technology, Nnamdi Azikiwe University, Awka. The fresh fruits were washed with sterile water and thereafter cut transversely with the aid of a sharp knife. The pulp, containing the aril and the seeds, were scooped out into a cheese cloth. The cheese cloth containing the fruit pulp was continuously squeezed until all the juice was extracted from the pulp. This was done separately for each treatment combination (genotype $x$ poultry manure rate or fertilizer) for each crop cycle.

\section{Data collection and analysis}

Data on fruit and juice metric traits were collected. These were fruit weight, fruit length, fruit circumference, fruit volume, aggregate juice volumes, individual and aggregate juice weights, pulp fresh weight, juice-to-fruit ratio and rind fresh weight. Juice volume was measured with a volumetric cylinder and expressed in millilitre $(\mathrm{ml})$. Juiceto-fruit ratio was determined as the ratio of the aggregate weight of juice and aggregate weight of fresh fruits.

Table 1. Physicochemical characteristics of composite soil sample of the experimental site and poultry manure used in 2014 and 2016

\begin{tabular}{|c|c|c|c|c|}
\hline \multirow{2}{*}{ Physical properties } & \multicolumn{2}{|c|}{2014} & \multicolumn{2}{|c|}{2016} \\
\hline & Top soil $(0-20 \mathrm{~cm})$ & Poultry manure & Top soil $(0-20 \mathrm{~cm})$ & Poultry manure \\
\hline $\mathrm{pH}\left(\mathrm{H}_{2} \mathrm{O}\right)$ & 5.00 & 8.8 & 5.70 & 8.1 \\
\hline $\mathrm{pH}(\mathrm{KCl})$ & 4.50 & 8.6 & & \\
\hline Organic carbon (\%) & 0.279 & 12.369 & 1.392 & 13.950 \\
\hline Organic matter (\%) & 0.482 & 21.324 & 2.062 & 24.062 \\
\hline Sand (\%) & 61 & - & 85 & - \\
\hline Silt (\%) & 7 & - & 9 & - \\
\hline Clay (\%) & 32 & - & 6 & - \\
\hline Textural class & Sandy clay loam & - & Sandy loam & - \\
\hline \multicolumn{5}{|l|}{ Chemical properties } \\
\hline Nitrogen (\%) & 0.154 & 2.942 & 0.126 & 3.643 \\
\hline Available phosphorus (ppm) & 20.00 & $0.953(\%)$ & 8.390 & $0.388(\%)$ \\
\hline Potassium (meq/100g) & Trace & $0.145(\%)$ & 0.108 & 3.881 \\
\hline Calcium (meq/100g) & 2.40 & 104.00 & 8.800 & 28.400 \\
\hline Magnesium(meq/100g) & 19.60 & 384.00 & 1.200 & 12.200 \\
\hline Sodium (meq/100g) & 1.243 & $0.0195(\%)$ & 0.072 & 1.724 \\
\hline $\begin{array}{c}\text { Cation exchangeable capacity } \\
\qquad(\mathrm{meq} / 100 \mathrm{~g})\end{array}$ & 26.00 & - & 16.00 & - \\
\hline Base saturation (\%) & 44.49 & - & 63.63 & - \\
\hline $\mathrm{Al}^{3+}(\mathrm{meq} / 100 \mathrm{~g})$ & - & - & Trace & - \\
\hline $\mathrm{H}^{+}(\mathrm{meq} / 100 \mathrm{~g})$ & 29.0 & - & 1.40 & - \\
\hline
\end{tabular}


424

Pulp fresh weight was the weight of the fruit juice together with the seeds. The weights of the juice, pulp and rind were measured with digital weighing balance ( $\mathrm{TH}$ 9801) and the results expressed in grams (g). Juice volume was measured with a measuring cylinder. The whole processes of juicing and measurements were done five times within September and October (peak period of fruit dropping) of each crop cycle.

Analysis of variance was carried out on the data obtained from the juicing processes following the procedure outlined for split-plot experiment using GENSTAT (2007). Mean separation of treatment means were done using Fisher's least significant difference at $5 \%$ significance level. Pearson product moment correlation coefficient was employed to determine significant relationship between some fruit and juice metric characteristics with the aid of SPSS 22.0.0 (SPSS, 2013).

\section{Results}

\section{Fruit metric traits of yellow passion fruit}

The KPF-4 genotype significantly $(\mathrm{p}<0.05)$ produced longer and wider fruits than the Conventional in 2015 (Table 2). Fruit volume and rind fresh weight were also higher with the KPF-4 fruits than the Conventional fruits. The fruit length, fruit circumference, fruit volume and rind fresh weight of fruits picked in 2017 did not significantly ( $p>0.05)$ differ between the two genotypes (Table 3 ).
Poultry manure rates significantly influenced some fruit characteristics in 2015 (Table 2). The fruit circumference $(20.09 \mathrm{~cm})$, fruit volume $\left(2163 \mathrm{~cm}^{3}\right)$ and rind fresh weight $(212.9 \mathrm{~g})$ were highest with the application of $40 \mathrm{t} \mathrm{ha}^{-1}$ poultry manure although the mean values did not significantly differ with 20 or $30 \mathrm{t} \mathrm{ha}^{-1}$ poultry manure application. However, there was $7.7 \%, 22 \%$ and $38 \%$ increase in fruit circumference, fruit volume and rind fresh weight of fruits produced with $40 \mathrm{t} \mathrm{ha}^{-1}$ poultry manure application compared with the fruits produced without poultry manure. In 2017 , all the fruit metric traits did not vary between the genotypes (Table 3 ).

The interaction of genotype and poultry manure rates in 2015 showed that highest mean values for fruit circumference $(21.33 \mathrm{~cm})$ and volume $\left(2595 \mathrm{~cm}^{3}\right)$ were produced by KPF-4 with $30 \mathrm{t} \mathrm{ha}^{-1}$ poultry manure application (Table 4). Rind fresh weight (252 g) was also highest in KPF- 4 but with $10 \mathrm{t} / \mathrm{ha}_{1}$ poultry manure application. Nonetheless, these mean values were not significantly $(p>0.05)$ different with the values recorded with other poultry manure rates applied to KPF-4. On the other hand, the interaction of genotype and fertilizer in 2017 indicated that fruit length $(11.08 \mathrm{~cm})$, fruit circumference $(21.29 \mathrm{~cm})$ and fruit volume $\left(2179 \mathrm{~cm}^{3}\right)$ were highest in the Conventional and KPF-4 (for fruit circumference) with $10 \mathrm{t} \mathrm{ha}^{-1} \mathrm{PM}+200 \mathrm{~kg} \mathrm{ha}^{-1} \mathrm{NPK}$ fertilizer application. Obviously, these values were significantly higher than the fruits that received no fertilizer (Table 5).

Table 2. Main effects of genotype and poultry manure rates on fruit metric traits of yellow passion fruit grown in the field in 2015

\begin{tabular}{ccccc}
\hline \multirow{2}{*}{ Genotype } & Fruit length $(\mathrm{cm})$ & Fruit circumference $(\mathrm{cm})$ & Fruit volume $\left(\mathrm{cm}^{3}\right)$ & Rind fresh weight $(\mathrm{g})$ \\
\cline { 2 - 5 } & \multicolumn{5}{c}{} & 1544 & 145.9 \\
\hline Conventional & 9.02 & 18.00 & 2417 & 224.4 \\
KPF-4 & 10.67 & 20.75 & 362.2 & 42.61 \\
\hline LSD0.05 & 0.65 & 1.18 & & 154.1 \\
\hline Poultry manure rate $(\mathrm{t} / \mathrm{ha})$ & & & 1768 & 203.8 \\
\hline 0 & 9.51 & 18.65 & 1958 & 170.0 \\
\hline 10 & 9.79 & 19.27 & 2007 & 185.0 \\
\hline 30 & 9.91 & 19.49 & 2009 & 212.9 \\
\hline LSD 0.05 & 9.90 & 19.39 & 2163 & 41.92 \\
\hline
\end{tabular}

Table 3. Main effects of genotype and fertilizer on fruit metric traits of two yellow passion fruit genotypes grown in the field in 2017

\begin{tabular}{ccccc}
\hline Genotype & Fruit length $(\mathrm{cm})$ & Fruit circumference $(\mathrm{cm})$ & Fruit volume $\left(\mathrm{cm}^{3}\right)$ & Rind fresh weight $(\mathrm{g})$ \\
\hline Conventional & 10.42 & 19.76 & 1914.0 & 222.8 \\
KPF-4 & 10.21 & 20.22 & 1928.0 & 236.3 \\
LSD0.05 & $\mathrm{ns}$ & $\mathrm{ns}$ & $\mathrm{ns}$ & $\mathrm{ns}$ \\
\hline Fertilizer & & & 1672.0 & 168.6 \\
\hline No fertilizer & 10.23 & 18.47 & 2076.0 & 246.6 \\
\hline $10 \mathrm{t} / \mathrm{ha}$ PM & 10.41 & 20.90 & 1921.0 & 248.2 \\
20 t/ha PM & 10.04 & 20.28 & 1900.0 & 233.1 \\
$5 \mathrm{t} / \mathrm{ha} \mathrm{PM+200} \mathrm{kg/ha} \mathrm{NPK}$ & 10.29 & 19.90 & 2178.0 & 249.4 \\
$10 \mathrm{t} / \mathrm{ha}$ PM+200 kg/ha NPK & 10.84 & 20.93 & 1779.0 & 231.3 \\
\hline $400 \mathrm{~kg} / \mathrm{ha} \mathrm{NPK}$ & 10.08 & 19.46 & 160.4 & 62.4 \\
\hline LSD0.05 & 0.54 & 0.65 & & \\
\hline
\end{tabular}


Table 4. Main effects of genotype and poultry manure rates on fruit metric traits of yellow passion fruit grown in the field in 2015

\begin{tabular}{|c|c|c|c|c|c|}
\hline Genotype & Poultry manure rate $(\mathrm{t} / \mathrm{ha})$ & Fruit length $(\mathrm{cm})$ & Fruit circumference $(\mathrm{cm})$ & Fruit volume $\left(\mathrm{cm}^{3}\right)$ & Rind fresh weight (g) \\
\hline \multirow[t]{5}{*}{ Conventional } & 0 & 8.79 & 17.27 & 1379 & 128.2 \\
\hline & 10 & 8.79 & 17.71 & 1453 & 155.7 \\
\hline & 20 & 9.06 & 18.36 & 1604 & 116.3 \\
\hline & 30 & 8.91 & 17.45 & 1422 & 136.0 \\
\hline & 40 & 9.57 & 19.21 & 1864 & 193.5 \\
\hline \multirow[t]{5}{*}{ KPF-4 } & 0 & 10.22 & 20.02 & 2157 & 180.0 \\
\hline & 10 & 10.79 & 20.84 & 2463 & 252.0 \\
\hline & 20 & 10.77 & 20.62 & 2409 & 223.6 \\
\hline & 30 & 10.89 & 21.33 & 2595 & 234.0 \\
\hline & 40 & 10.70 & 20.96 & 2462 & 232.4 \\
\hline LSD 0.05 & & $\mathrm{~ns}$ & 1.20 & 376.8 & 59.74 \\
\hline
\end{tabular}

Table 5. Combined effect of genotype and fertilizer on fruit metric traits of two yellow passion fruit genotypes grown in the field in 2017

\begin{tabular}{|c|c|c|c|c|c|}
\hline Genotype & Fertilizer & Fruit length $(\mathrm{cm})$ & Fruit circumference $(\mathrm{cm})$ & Fruit volume $\left(\mathrm{cm}^{3}\right)$ & Rind fresh weight $(\mathrm{g})$ \\
\hline \multirow[t]{6}{*}{ Conventional } & No fertilizer & 10.81 & 19.58 & 1994.0 & 170.2 \\
\hline & $10 \mathrm{t} / \mathrm{ha} \mathrm{PM}$ & 10.45 & 20.84 & 2093.0 & 234.7 \\
\hline & $20 \mathrm{t} / \mathrm{ha} \mathrm{PM}$ & 9.61 & 19.67 & 1764.0 & 261.0 \\
\hline & $5 \mathrm{t} / \mathrm{ha} \mathrm{PM}+200 \mathrm{~kg} / \mathrm{ha} \mathrm{NPK}$ & 10.31 & 19.18 & 1797.0 & 245.5 \\
\hline & $10 \mathrm{t} / \mathrm{ha} \mathrm{PM}+200 \mathrm{~kg} / \mathrm{ha}$ NPK & 11.08 & 20.57 & 2179.0 & 208.8 \\
\hline & $400 \mathrm{~kg} / \mathrm{ha}$ NPK & 10.24 & 18.74 & 1707.0 & 216.2 \\
\hline \multirow[t]{6}{*}{ KPF-4 } & No fertilizer & 9.65 & 17.35 & 1400.0 & 167.0 \\
\hline & $10 \mathrm{t} / \mathrm{ha} \mathrm{PM}$ & 10.37 & 20.96 & 2059.0 & 258.5 \\
\hline & 20 t/ha PM & 10.47 & 20.89 & 2077.0 & 235.3 \\
\hline & 5 t/ha PM+200 kg/ha NPK & 10.28 & 20.61 & 2002.0 & 252.9 \\
\hline & $10 \mathrm{t} / \mathrm{ha} \mathrm{PM}+200 \mathrm{~kg} / \mathrm{ha}$ NPK & 10.60 & 21.29 & 2177.0 & 257.3 \\
\hline & $400 \mathrm{~kg} / \mathrm{ha} \mathrm{NPK}$ & 9.92 & 20.19 & 1852.0 & 246.4 \\
\hline $\mathrm{LSD}_{0.05}$ & & 0.76 & 1.31 & 272.1 & ns \\
\hline
\end{tabular}

\section{Juice metric traits of yellow passion fruit}

In 2015, aggregate juice volume, juice weight and pulp fresh weight did not significantly vary between the two passion fruit genotypes (Table 6). But juice-to-fruit ratio (0.369) was higher in the Conventional than in the KPF-4 genotype. In contrast, rind fresh weight $(1247 \mathrm{~g})$ was higher in KPF-4 than the Conventional. The poultry manure rates only influenced the juice-to-fruit ratio and rind fresh weight (Table 6). Highest juice-to-fruit ratio and rind fresh weight were produced by the application of 20 and $40 \mathrm{t} \mathrm{ha}^{-1}$, respectively. Fruits with higher juice percentage had lower mean rind fresh weight and vice versa. On the other hand, all the juice metric characteristics in 2017 did not significantly $(p>0.05)$ differ between the genotypes (Table 7). Aggregate juice volume, fresh and dry weights of rinds were significantly higher when the vines received $10 \mathrm{tha}^{-1}$ $\mathrm{PM}+200 \mathrm{~kg} \mathrm{ha}^{-1} \mathrm{NPK}$ than when the vines received no fertilizer.
The combined effect of genotype and poultry manure rates in 2015 indicated that the aggregate juice volume (682 $\mathrm{ml})$, juice weight $(709 \mathrm{~g})$, pulp fresh weight $(942 \mathrm{~g})$ and seed-aril fresh weight $(175 \mathrm{~g})$ were significantly highest in the Conventional genotype when they received $40 \mathrm{t} / \mathrm{ha}$ poultry manure (Table 8). But growing the Conventional genotype with $30 \mathrm{t} \mathrm{ha}^{-1}$ poultry manure resulted in lowest juice volume $(410 \mathrm{ml})$ and juice weight $(421 \mathrm{~g})$.

The interaction effect of genotype and fertilizer on the fruit and juice metric traits in 2017, showed that highest aggregate juice volume $(723 \mathrm{ml})$, juice weight $(706 \mathrm{~g})$ and pulp fresh weight $(770 \mathrm{~g})$ were produced by the Conventional genotype with $10 \mathrm{t} \mathrm{ha}^{-1} \mathrm{PM}+200 \mathrm{~kg} \mathrm{ha}^{-1}$ NPK application (Table 9). The juice-to-fruit ratio (0.537) was highest in KPF-4 when $5 \mathrm{tha}^{-1} \mathrm{PM}+200 \mathrm{~kg} \mathrm{ha}^{-1} \mathrm{NPK}$ was applied. The heaviest fresh fruit rind was produced by the Conventional with $20 \mathrm{t} /$ ha poultry manure application.

Table 6. Main effects of genotype and poultry manure rates on juice metric traits of yellow passion fruit grown in the field in 2015

\begin{tabular}{|c|c|c|c|c|c|}
\hline Genotype & Aggregate juice volume $(\mathrm{ml})$ & Aggregate juice weight (g) & Juice-to-fruit ratio & Pulp fresh weight $(\mathrm{g})$ & Rind fresh weight $(\mathrm{g})$ \\
\hline Conventional & 537.0 & 558.0 & 0.369 & 727.0 & 811.0 \\
\hline KPF-4 & 533.0 & 568.0 & 0.298 & 726.0 & 1247.0 \\
\hline $\mathrm{LSD}_{0.05}$ & ns & $\mathrm{ns}$ & 0.014 & ns & 236.8 \\
\hline \multicolumn{6}{|c|}{ Poultry manure rate $(\mathrm{t} / \mathrm{ha})$} \\
\hline 0 & 466.0 & 486.0 & 0.362 & 657.0 & 856.0 \\
\hline 10 & 562.0 & 586.0 & 0.315 & 780.0 & 1132.0 \\
\hline 20 & 572.0 & 627.0 & 0.364 & 730.0 & 944.0 \\
\hline 30 & 497.0 & 515.0 & 0.322 & 709.0 & 1028.0 \\
\hline 40 & 576.0 & 600.0 & 0.306 & 757.0 & 1183.0 \\
\hline $\mathrm{LSD}_{0.05}$ & ns & ns & 0.037 & ns & 232.9 \\
\hline
\end{tabular}


Table 7. Main effects of genotype and fertilizer on some fruit and juice metric traits of yellow passion fruit grown in the field in 2017

\begin{tabular}{|c|c|c|c|c|c|c|}
\hline & $\begin{array}{c}\text { Aggregate juice } \\
\text { volume (ml) }\end{array}$ & $\begin{array}{l}\text { Aggregate juice } \\
\text { weight }(\mathrm{g})\end{array}$ & $\begin{array}{l}\text { Juice-to-fruit } \\
\text { ratio }\end{array}$ & $\begin{array}{l}\text { Pulp fresh weight } \\
\text { (g) }\end{array}$ & $\begin{array}{l}\text { Rind fresh weight } \\
\text { (g) }\end{array}$ & $\begin{array}{c}\text { Rind dry weight } \\
\text { (g) }\end{array}$ \\
\hline \multicolumn{7}{|l|}{ Genotype } \\
\hline Conventional & 601 & 593 & 0.47 & 661 & 222.8 & 23.6 \\
\hline KPF-4 & 530 & 567 & 0.49 & 589 & 236.3 & 27.8 \\
\hline $\mathrm{LSD}_{0.05}$ & ns & Ns & ns & ns & ns & ns \\
\hline \multicolumn{7}{|l|}{ Fertilizer } \\
\hline No fertilizer & 519 & 599 & 0.487 & 606 & 168.6 & 22.7 \\
\hline $10 \mathrm{t} / \mathrm{ha} \mathrm{PM}$ & 523 & 520 & 0.450 & 572 & 246.6 & 32.4 \\
\hline 20 t/ha PM & 504 & 538 & 0.476 & 557 & 248.2 & 33.2 \\
\hline $5 \mathrm{t} / \mathrm{ha} \mathrm{PM}+200 \mathrm{~kg} / \mathrm{ha}$ NPK & 591 & 585 & 0.491 & 658 & 233.1 & 31.8 \\
\hline $\begin{array}{c}10 \mathrm{t} / \mathrm{ha} \mathrm{PM}+200 \mathrm{~kg} / \mathrm{ha} \\
\text { NPK }\end{array}$ & 668 & 658 & 0.501 & 716 & 249.4 & 35.9 \\
\hline $400 \mathrm{~kg} / \mathrm{ha}$ NPK & 589 & 579 & 0.477 & 640 & 231.3 & 31.2 \\
\hline LSD0.05 & 120.4 & ns & ns & ns & 62.4 & 2.5 \\
\hline
\end{tabular}

Table 8. Interaction effect of genotype and poultry manure rates on juice metric traits of yellow passion fruit grown in the field in 2015

\begin{tabular}{ccccccc}
\hline Genotype & $\begin{array}{c}\text { Poultry manure rate } \\
(\mathrm{t} / \mathrm{ha})\end{array}$ & $\begin{array}{c}\text { Aggregate juice volume } \\
(\mathrm{ml})\end{array}$ & $\begin{array}{c}\text { Aggregate juice weight } \\
(\mathrm{g})\end{array}$ & $\begin{array}{c}\text { Juice-to-fruit } \\
\text { ratio }\end{array}$ & $\begin{array}{c}\text { Pulp fresh } \\
\text { weight }(\mathrm{g})\end{array}$ & $\begin{array}{c}\text { Rind fresh } \\
\text { weight }(\mathrm{g})\end{array}$ \\
\hline Conventional & 0 & 453.0 & 471.0 & 0.403 & 634.0 & 712.0 \\
& 10 & 512.0 & 535.0 & 0.333 & 715.0 & 865.0 \\
& 20 & 625.0 & 655.0 & 0.407 & 726.0 & 646.0 \\
& 30 & 410.0 & 421.0 & 0.342 & 619.0 & 755.0 \\
KPF-4 & 40 & 682.0 & 709.0 & 0.361 & 942.0 & 1075.0 \\
& 0 & 480.0 & 502.0 & 0.321 & 681.0 & 1000.0 \\
& 10 & 612.0 & 638.0 & 0.296 & 844.0 & 1400.0 \\
& 20 & 520.0 & 598.0 & 0.319 & 735.0 & 1243.0 \\
& 30 & 584.0 & 609.0 & 0.301 & 799.0 & 1300.0 \\
LSD0.05 & 40 & 471.0 & 491.0 & 0.250 & 572.0 & 1292.0 \\
\hline
\end{tabular}

Table 9. Combined effect of genotype and fertilizer on some fruit and juice metric traits of yellow passion fruit grown in the field in 2017

\begin{tabular}{|c|c|c|c|c|c|c|c|}
\hline Genotype & Fertilizer & $\begin{array}{l}\text { Aggregate juice } \\
\text { volume (ml) }\end{array}$ & $\begin{array}{c}\text { Aggregate juice } \\
\text { weight }(\mathrm{g})\end{array}$ & $\begin{array}{l}\text { Juice-to-fruit } \\
\text { ratio }\end{array}$ & $\begin{array}{l}\text { Pulp fresh } \\
\text { weight (g) }\end{array}$ & $\begin{array}{l}\text { Rind fresh } \\
\text { weight }(\mathrm{g})\end{array}$ & $\begin{array}{l}\text { Rind dry weight } \\
\text { (g) }\end{array}$ \\
\hline \multirow[t]{6}{*}{ Conventional } & No fertilizer & 580 & 588 & 0.445 & 670 & 170.2 & 21.5 \\
\hline & 10 t/ha PM & 576 & 561 & 0.474 & 630 & 234.7 & 33.4 \\
\hline & $20 \mathrm{t} / \mathrm{ha} \mathrm{PM}$ & 568 & 559 & 0.445 & 609 & 261.0 & 33.6 \\
\hline & $5 \mathrm{t} / \mathrm{ha} \mathrm{PM}+200 \mathrm{~kg} / \mathrm{ha} \mathrm{NPK}$ & 521 & 521 & 0.446 & 770 & 245.8 & 35.6 \\
\hline & $10 \mathrm{t} / \mathrm{ha} \mathrm{PM}+200 \mathrm{~kg} / \mathrm{ha} \mathrm{NPK}$ & 723 & 706 & 0.524 & 600 & 208.8 & 27.4 \\
\hline & $400 \mathrm{~kg} / \mathrm{ha}$ NPK & 636 & 624 & 0.510 & 684 & 216.0 & 28.4 \\
\hline \multirow[t]{6}{*}{ KPF-4 } & No fertilizer & 457 & 610 & 0.528 & 543 & 167.0 & 20.6 \\
\hline & 10 t/ha PM & 470 & 480 & 0.426 & 515 & 258.5 & 37.8 \\
\hline & $20 \mathrm{t} / \mathrm{ha} \mathrm{PM}$ & 439 & 516 & 0.506 & 505 & 235.3 & 34.2 \\
\hline & $5 \mathrm{t} / \mathrm{ha} \mathrm{PM}+200 \mathrm{~kg} / \mathrm{ha} \mathrm{NPK}$ & 661 & 650 & 0.537 & 716 & 252.9 & 33.4 \\
\hline & $10 \mathrm{t} / \mathrm{ha} \mathrm{PM}+200 \mathrm{~kg} / \mathrm{ha}$ NPK & 613 & 611 & 0.477 & 662 & 257.3 & 33.6 \\
\hline & $400 \mathrm{~kg} / \mathrm{ha} \mathrm{NPK}$ & 542 & 535 & 0.444 & 596 & 246.4 & 36.9 \\
\hline LSD $_{0.05}$ & & 175.2 & $\mathrm{~ns}$ & 0.132 & 172.4 & 82.29 & $\mathrm{~ns}$ \\
\hline
\end{tabular}

Correlations between fruit metric traits and juice metric characteristics

Results of the correlation indicated that aggregate fruit weight and rind fresh weight had significant $(p<0.01)$ positive and strong association with the juice volume, juice weight and pulp fresh weight in both 2015 and 2017 (Table 10). Stronger relationship existed between the aggregate fruit weight and the juice metric traits than the rind fresh weight. For instance, correlation coefficients between aggregate fruit weight and juice traits in 2015 were $r=$ $0.814^{* *}, 0.815^{* *}$ and $0.820^{* *}$ for juice volume, juice weight and pulp fresh weight, respectively. In 2017, the correlation coefficients were $\mathrm{r}=0.890^{* *}, 0.933^{* *}$ and $0.950^{* *}$, respectively for juice volume, juice weight and pulp fresh weight. In comparison to aggregate fresh weight, the rind 
Table 10. Correlation coefficients of some fruit and juice metric traits in 2015 and 2017

\begin{tabular}{|c|c|c|c|c|c|c|}
\hline & \multicolumn{3}{|c|}{2015} & \multicolumn{3}{|c|}{2017} \\
\hline & $\begin{array}{l}\text { Juice volume } \\
(\mathrm{ml})\end{array}$ & $\begin{array}{c}\text { Juice weight } \\
(\mathrm{g})\end{array}$ & $\begin{array}{l}\text { Pulp fresh weight } \\
\text { (g) }\end{array}$ & $\begin{array}{l}\text { Juice volume } \\
(\mathrm{ml})\end{array}$ & $\begin{array}{l}\text { Juice weight } \\
\text { (g) }\end{array}$ & $\begin{array}{l}\text { Pulp fresh weight } \\
\text { (g) }\end{array}$ \\
\hline Aggregate fresh fruit weight $(\mathrm{g})$ & .814 & .815 & $.820^{\circ}$ & $.890^{\circ}$ & $.933^{\circ}$ & $.950^{\circ}$ \\
\hline Fruit length $(\mathrm{cm})$ & .243 & .296 & .219 & .188 & 128 & .067 \\
\hline Fruit circumference $(\mathrm{cm})$ & .303 & $.345^{\circ}$ & .282 & .199 & .259 & .255 \\
\hline Fruit volume $\left(\mathrm{cm}^{3}\right)$ & .284 & .336 & .267 & .235 & .240 & .211 \\
\hline Rind fresh weight (g) & $.535^{\circ}$ & $.545^{\circ}$ & $.678^{\prime \prime}$ & .796 & $.818^{\prime \prime}$ & .816 \\
\hline
\end{tabular}

fresh weight had weaker and positive correlation with the juice metric traits in both years $\left(\mathrm{r}=0.535^{* *}, 0.545^{* *}\right.$ and $0.678^{* *}$ for juice volume, juice weight and pulp fresh weight, respectively in 2015 and $\mathrm{r}=0.796^{* *}, 0.818^{* *}$ and $0.816^{* *}$ in 2017). On the other hand, juice weight in 2015 had significant positive but weak relationship with the fruit circumference $\left(r=0.345^{*}\right)$ and fruit volume $\left(0.336^{*}\right)$.

\section{Discussion}

The variations observed in the fruit length, fruit circumference, rind fresh weight and juice-to-fruit ratio between the two yellow passion fruit genotypes confirmed that the hybrid, KPF- 4 are bigger in size as reported by KARLOS (2014). The present study is also in agreement with the report of Ndukwe and Baiyeri (2018a). However, the bigger size of the KPF-4 was not translated to higher juice percentage as claimed by KARLOS (2014). This therefore suggested the need to carry out a detailed characterization of the Conventional genotype which will be significant in revealing the genetic make-up for comparisons with the hybrid, KPF-4. The range of juice percentage (30-37\% and $47-49 \%$ in 2015 and 2017, respectively) were in conformity with the percentages (30$34 \%$ for Passiflora edulis) reported by Sema and Maiti (2006).

The significant increase of the aggregate juice volume, juice weight, pulp fresh weight with the addition of fertilizers (20 or $40 \mathrm{t} / \mathrm{ha} \mathrm{PM}$ and $10 \mathrm{t} / \mathrm{ha} \mathrm{PM}+200 \mathrm{~kg} / \mathrm{ha}$ NPK in the 2014 and 2016 seasons, respectively) indicated the role of fertilization with respect to nutrient supply and corresponding availability to the vines. The poultry manure and NPK utilized in this study were rich in nutrients such as potassium and nitrogen which are important elements in fresh fruit juice production. Potassium not only improves yields but also benefits other aspects of fruit quality; hence, there is higher potassium demand during fruit development (Ramesh et al., 2006). Water use efficiency is also dependent on the potassium concentration of the soil. The juice yield of pineapple was reported to be higher when organic fertilizer (Phos-K) was applied (Owureku-Asare, 2015). In addition, nitrogen nutrition in the vine must have been improved since good potassium nutrition favours rapid conversion of inorganic nitrogen (ammonia and nitrate) into to proteins (Ramesh et al., 2006). Ndukwe and Baiyeri (2018b) earlier noted that crude protein of passion fruit juice increased with increase in poultry manure rates $(40$ t/ha).
Increased poultry manure rate in 2014 and the combined application of poultry manure and NPK in 2016 increased passion fruit juice yield implying that more beneficial soil nutrients were supplied and utilized by the vine for the production of more juice. This is in conformity with an earlier study which reported an increase in juice concentration of sweet passion fruit with increase in nitrogen doses especially with addition of cattle manure (Dutra et al., 2016). The combination of organic and inorganic fertilizers has positive and complementary effects on the availability of soil plant nutrients and improvement of soil biophysical characteristics. These complementary advantages of combining organic and inorganic fertilizers enhanced better absorption of nutrients and their utilization for higher juice production among other fruit metric traits. The present study corroborates with previous reports indicating that increased fertilizer rate increased juice volume and percentage of passion fruit (Ani and Baiyeri, 2008), kinnow mandarin (Garhwal et al., 2014) and sweet sorghum (Kering et al., 2017).

The significant, positive and strong relationships that existed between aggregate fruit weight and juice volume, juice weight and pulp fresh weight in 2015 and 2017 is an indication that any agronomic practice that can increase the fruit weight will also increase the juice metric traits. Hence, the juice metric traits can be predicted from the fruit weight.

\section{Conclusions}

The KPF-4 genotypes produced longer, wider and heavier fruits than the Conventional in 2015 whereas in 2017 all the fruit and juice metric traits were not significantly $(p>0.05)$ different between the Conventional and KPF- 4 genotypes. Higher juice percentage and fruit metric traits of yellow passion fruit can be produced with the addition of $20 \mathrm{t} / \mathrm{ha}$ poultry manure, considering lesser cost of poultry manure procurement. The subsequent season of fruit production showed that the combination of either $5 \mathrm{t} / \mathrm{ha}$ or $10 \mathrm{t} / \mathrm{ha}$ poultry manure and $200 \mathrm{~kg} / \mathrm{ha}$ NPK enhanced higher quantity of juice production. The aggregate fruit weight and rind fresh weight were strongly correlated to the pulp fresh weight, juice volume and juice weight, implying that industries or individuals can predict the juice volume and pulp fresh weight from the fresh fruit weight. 
428

\section{Acknowledgements}

This work was supported by the Tertiary Education Trust Fund of the Federal Republic of Nigeria.

\section{Conflict of Interest}

The authors declare that there are no conflicts of interest related to this article.

\section{References}

AniJU, Baiyeri KP (2008). Impact of poultry manure and harvest season on juice quality of yellow passion fruit (Passiflora edulis var. Alavicarpa Deg) in the sub-humid zone of Nigeria. Fruits 63(4):239-247.

Aular J, Casares M, Natale W (2014). Mineral nutrition and fruit quality of pineapple and passion fruit. Revista Brasileira de Fruticultura 36(4):1046-1054.

Chau C, Huang Y (2004). Characterization of passion fruit seed fibers - a potential fiber source. Food Chemistry 85(2):189-194.

Chau C, Huang Y, Chang F (2005). Effects of fiber derived from passion fruit seed on the activities of ileum mucosal enzymes and colonic bacterial enzymes in hamsters. Journal of the Science of Food and Agriculture 85(12):2119-2124.

da Silva MAP, Plácido GR, Caliari M, Carvalho B deS, da Silva RM, Cagnin C, ... da Silva CF (2015). Physical and chemical characteristics and instrumental color parameters of passion fruit (Passiflora edulis Sims). African Journal of Agricultural Research 10(10):119-1126.

Dutra GAP, de Carvalho AJC, Freitas MSM, dos Santos PC, Freitas JAA, Marinho CS (2016). Sweet passion fruit yield and fruit quality related to fertilization with urea and cattle manure. Journal of Plant Nutrition 39(6):828-834.

Ferreres F, Sousa C, Valentao P, Andrade PB, Seabra RM, Gil-Izquierdo A (2007). New C-Deoxyhexosyl flavones and antioxidant properties of Passiflora edulis leaf extract. Journal of Agricultural and Food Chemistry 55(25):10187-10193.

Garhwal PC, Yadav PK, Sharma BD, Singh RS, Ramniw AS (2014).Effect of organic and nitrogen on growth yield and quality of kinnow mandarin in sandy soils of hot arid region. African Journal of Agricultural Research 9(34):2638-2647.

GENSTAT (2007). GENSTAT for Windows. Release 7.2DE Discovery Edition 3. Lawes Agricultural Trust (Rothamsted Experimental Station). VSN International Ltd., Hemel Hempstead, UK.

KARLOS (Kenya Agricultural Research and Livestock Organization) (2014). KARI sweet yellow passion that withstand critical diseases that ravaged purple passion. Hortfresh Journal. Tech Era Communication, Nairobi, Kenya.
Kering MK, Temu VW, Rutto, LK (2017). Nitrogen fertilizer and panicle removal in Sweet Sorghum production: Effect on biomass, juice yield and soluble sugar content. Journal of Sustainable Bioenergy Systems 7(01):14-26.

Knight RJ, Sauls JW (2005). The passion fruit. Factsheet HS No. 60 (Reviewed Edition), Horticultural Science Department, Florida Cooperative Extension Service, Institute of Food and Agricultural Science University of Florida.

Mattheis JP, Fellman JK(1999). Preharvest factors influencing flavor of fresh fruit and vegetables. Postharvest Biology and Technology 15(3):227232.

Mwirigi P, Mwangi M, Gweyi-Onyango J (2016). Agronomic management of yellow passion fruit among farmers in Mbeere sub-county, Kenya. African Journal of Horticultural Science 10:1-13.

Ndukwe OO, Baiyeri KP (2018a). Influence of genotype and poultry manure rate on phenology and fruit yield of yellow passion fruit. Acta Horticulturae 1225:139-144.

Ndukwe OO, Baiyeri KP (2018b). Biochemical characterisation of fruit juice from two yellow passion fruit genotypes as influenced by poultry manure rates. Acta Horticulturae 1225:295-302.

Owureku-Asare M, Agyei-Amponsah J, Agbemavor SWK, Apatey J, Sarfo AK, Okyere AA, ... Dodobi MT (2015). Effect of organic fertilizers on physical and chemical quality of sugar loaf pineapple (Ananas comosus L.) grown in two ecological sites in Ghana. African Journal of Food, Agriculture, Nutrition and Development 15(2):9982-9995.

Pacheco ALV, Borges KS, de Freitas GB, Vieira G (2017). Yield and quality of yellow passion fruits according to organic fertilization and alternative phytosanitary management. Revista Brasileira de Agropecuária Sustentável(RBAS) 7(3):8490.

Ramesh KA, Kumar N, Kavino M (2006). Role of potassium in fruit crops a review. Agricultural Reviews 27(4):284291.

Sano S, Sugiyama K, Ito T, Katano Y, Ishihata A (2011). Identification of the strong vasorelaxing substance scirpusin $B$, a dimer of piceatannol, from passion fruit (Passiflora edulis) seeds. Journal of Agricultural and Food Chemistry59(11):6209-6213.

Sema A, Maiti CS (2006). Status and prospects of passion fruit industry in Northeast India. Central Institute of Horticulture, Medziphema-797 106, Nagaland.

SPSS (2013). IBM SPSS Statistics Version 22, Release 22.0.0.0. IBM Corporation and other (s) 1989.

Weston LA, Barth MM (1997). Preharvest factors affecting postharvest quality of vegetables. HortScience 32(5):812-816. 